\title{
Educational Trajectories \\ Through Secondary \\ Education in Luxembourg: \\ How Does Permeability \\ Affect Educational \\ Inequalities?
}

\section{Susanne Backes and Andreas Hadjar}

The link between stratification and educational inequality in empirical research is well documented. Some countries - particularly those that do not follow the model of comprehensive schools - discuss the possibility of increasing permeability between school tracks to reduce inequalities. This paper focuses on the occurrence of permeability in the stratified school system of Luxembourg and examines what this permeability entails for certain risk groups, specifically students from lower social background, male students and migrants. Educational pathways were classified (cluster analysis) on the basis of an administrative panel data set ( $n=5301)$; mechanisms behind educational decisions were analysed as a second step by estimating logistic regressions (Boudon, 1974). The findings show that reorientations in Luxembourg are often determined by the students' social group, and that permeability - as blurred educational boundaries - mainly reproduces disparities in track placement.

\section{Introduction}

Since the second part of the $20^{\text {th }}$ century, educational equality is mentioned in international conventions as the main goal of industrialised countries - in response to empirical evidence showing the disadvantage of educational disparities for groups such as working-class students (Meyer \& Ramirez, 2005). A well-known finding in educational research is the association between external differentiation of secondary school tracks (stratification) and educational inequality (Pfeffer, 2008; Van de Werfhorst \& Mijs, 2010). In this context, a variety of potential modifications of education systems is controversially discussed, such as untracking (for the US: Oakes, 2005 vs. Loveless, 1999) or permeability between school tracks (for Germany: Cortina, 2003 vs. Mauthe \& Rösner, 1998). In regard to stratified education systems with an early tracking of students, permeability is often mentioned as an antidote against injustice and inequalities. From this perspective, higher permeability is understood as «softening» educational boundaries between school tracks. Although stratified 
systems are associated with educational inequalities, those systems differ in the structures which provide opportunities for intragenerational social mobility through re-orientation during secondary school. However, studies on stratified school systems, such as those existing in Germany, have shown that permeable structures - or «blurred boundaries» - are social-selectively used (Jacob, 2004), which implies that certain groups (e.g., upper social class) benefit more from permeability than others (e.g., lower social class). According to Boudon (1974), this can be explained via group-specific educational decisions. Drawing on this debate, the paper focuses on the occurrence of permeability in the stratified educational system of Luxembourg and examines whether or not permeability decreases educational inequalities by analysing what permeability entails for specific groups of students.

In Luxembourg, educational disadvantages of migrants, working-class students and male students - in terms of placement and achievement gaps - are well documented (Hadjar, Fischbach, Martin \& Backes, 2015). Nonetheless, educational pathways of these risk groups represent a black box in the research field. As a consequence, the aim of this paper is to examine which types of pathways emerge and to what extent (dis)continuous pathways and re-orientations correlate with axes of inequality. Accordingly, this paper raises the following research questions: (1) How can students' pathways through Luxembourg's educational system be characterised and how do different pathway types vary depending on social origin, gender and migration background? (2) What are the mechanisms behind track changes and does the use of track changes increase or decrease educational inequalities? The findings are based on an administrative panel-data set of all students born in 1990 and enrolled in any of the secondary schools governed by the Ministry of Education ( $\mathrm{n}=5301)$.

The paper is structured as follows: a brief definition of the terms permeability and educational inequality will be followed by an overview of the public and scientific debate on the effectiveness of permeability. Then a theoretical framework based on the concept of Boudon (1974) will be introduced followed by a description of the institutional features of Luxembourg's school system. Before the findings are discussed, data set, operationalisations and the study design are presented, followed by the results from secondary data analyses, including cluster analysis and logistic regression models.

\section{Permeability and inequalities: public and political hopes and state-of-research}

Permeability refers to opportunities for changes in educational pathways of education systems, which are primarily characterised by a rather stratified secondary education with distinct school tracks. Often such track changes go along with social mobility - upwards or downwards. While the term vertical 
permeability refers to transitions between successive stages of education (e.g., from lower to upper secondary education), our analyses focus on horizontal permeability, which is defined as transitions between parallel secondary school tracks characterised by distinct ability levels, curricula, certificates offered and occupational options (Bellenberg, 2012; Kemnade, 1989). This research issue is also specified by the terms of intra-secondary mobility or intra-secondary transitions (Jacob \& Tieben, 2007). As will be shown, not only vertical permeability, but also horizontal permeability is linked to educational inequalities. Non-permeability refers to barriers that minimise such opportunities, such as institutional settings of education systems or school-specific practices. Regarding permeability and educational trajectories, this study considers each end of a school year as a potential transition point, since students may or may not transit to the next grade, or experience a track change. As we try to discover who is more likely to experience certain educational trajectories, educational inequalities are at the centre of this study. Educational inequalities are defined as systematic variations in certain aspects of education (here: educational trajectories including upward and downward transitions) that are structured by certain axes of inequality (here: social origin, gender and migration background).

Structural characteristics of an education system that might cause inequalities are highly discussed, particularly in stratified school systems like Germany. Comprehensive and, thus, lowly-stratified education systems - according to empirical evidence being less prone to educational inequalities (Hadjar \& Becker, 2016) - are a much debated issue since the 1970s. Although comprehensive schooling systems in many countries have been functioning well for decades (e.g., in Scandinavian countries), this practice is a kind of taboo in Luxembourg (Backes, 2018; Hadjar \& Rothmüller, 2016) and only introduced to some regions in other countries due to high objection (Hadjar \& Becker, 2011). Therefore, in Germany, measures enabling permeability became an alternative strategy to reduce educational inequalities (Cortina, 2003; Hillmert \& Jacob, 2005). As such measures did not radically change the stratified schooling system and as school track recommendations imply a certain degree of uncertainty, there was a relatively broad political consensus on the meaningfulness of raising permeability (Kemnade, 1989). However, empirical evidence is ambivalent: while, in Germany, Mauthe and Rösner (1998, p. 123) conclude from their secondary data analysis that permeability is a "myth», Cortina (2003) states that permeability is a frequent phenomenon. In regard to the assumed inequality-reducing function of permeability, studies show rather unintended consequences: as different groups of students experience different kinds of track changes and, thus, different kinds of mobility, they benefit differently from permeability (Jacob, 2004). As students originating from privileged social backgrounds are more likely to experience upward mobility, that is to say permeability in terms of "second chances," inequalities are more reproduced than reduced (Stubbe, 2009). From a literature review combined with re-analyses of longitudinal 
German data sets, Schindler (2015) concludes that these findings primarily refer to conditional mobility rates describing educational inequalities at a particular branching point (only looking at those individuals that still have the possibility to use this particular transition option). Analyses of unconditional mobility rates (considering the entire group sizes of those who are at risk) show that the effect of mobility in or after secondary education (caused by track placement) on educational inequalities depends on contextual circumstances such as birth cohort-specific conditions (Schindler, 2017).

\section{Theoretical framework and hypothetical scenarios}

The general theory of educational inequalities provided by Boudon (1974) is focused on primary and secondary effects and can also be applied to intra-secondary school transitions since track changes are based on the student's achievement and educational decisions. Focusing on social origin, Boudon makes a distinction between primary and secondary effects. Primary effects refer to class-specific educational achievement. If working-class students, who are primarily oriented towards lower school tracks at the transition to secondary school, show higher achievements, they may also be more likely to experience future upward track changes in terms of corrections of the tracking decision. However, we could also assume that the lower achievements of students originating from working-class families results more often in stable trajectories in lower school tracks or downward mobility. Secondary effects of social origin relate to educational transitions based on class-specific evaluations of the benefit of education (including status maintenance), costs of educational pathways and the probability to successfully finish particular school tracks. As working-class families perceive a lower benefit and higher costs of upper educational pathways, and, furthermore, think that their offspring is less able to successfully graduate, they also opt for upward track changes to a lower extent than families of privileged origins. For the same reasons, teachers might also opt less often for upward track changes for working class students. The framework of primary and secondary effects can also be applied to gender differences in educational trajectories (Becker \& Müller, 2011; Hadjar \& Buchmann, 2016). Boys' lower achievement (Becker, 2014; Francis, 2000) may go along with a higher probability to experience stable trajectories in lower tracks or downward mobility. Finally, looking at ethnicity primary and secondary effects can also be expected (Kristen \& Dollmann, 2010): while immigrants often suffer from language problems or a lack of knowledge regarding the education systems (primary effects), they show higher educational aspirations than native students, as they perceive education as a main instrument for a successful integration into the host society (Becker \& Schubert, 2011; Kao \& Tienda, 1998). Thus, it can be 
assumed that immigrant families are more likely than natives to encourage track changes that lead to upward mobility (positive secondary effects). However, migrants are not a homogeneous group so that different ethnicities and social groups need to be distinguished (Griga \& Hadjar, 2013).

\section{The education system of Luxembourg}

The Luxembourgish secondary education system shares some characteristics with Switzerland and Germany, such as a high vocational specificity and a high degree of stratification/external differentiation. After grade six in primary school, students are oriented towards one of three main tracks for secondary education starting from grade seven: an academic secondary track (enseignement secondaire, ES) preparing for a later transition to university, a technical secondary track (enseignement secondaire technique, EST) which is further subdivided in different ability levels (théorique as the highest technical track, polyvalente and pratique as lower technical tracks) and a vocational track (préparatoire) mainly preparing for the later transition to vocational training or the direct transition to the labour market in terms of the lowest educational track in Luxembourg (see figure 1; Ministère de l'Éducation nationale et de la Formation professionnelle [MENFP], 2011). For legibility reasons, we will use the terms academic track (ES), technical tracks (EST) and vocational track (préparatoire). The track orientation after primary school is a binding decision made by a commission. At the end of lower secondary school grade 9, students in the technical tracks (EST) pass through an institutionalised orientation phase and receive a school track recommendation (avis d'orientation), which, upon consideration of the attended school track and school marks in grade 9, grants permission for particular school tracks in grade 10. The tracks starting from grade 10 (Régime technique, Formation technicien, CATP, CCM, CITP; see figure 1) end with different certificates: two of them (Régime technique, Formation technicien) give students the possibility to attend higher education in terms of a technical upper secondary general track, while the remaining tracks are vocation-oriented tracks with decreasing amount of theory in the curriculum, increasing hours spent in the training company and decreasing status and future income (MENFP, 2012). Thus, the stratified school system of Luxembourg demands several educational decisions from teachers, parents and students, and can be characterised as a separation model that follows a principle of homogenisation in dealing with heterogeneous students. This is of peculiar interest due to the large part of immigrants living in Luxembourg ( $45 \%$; Institut national de la statistique et des études économiques du GrandDuché de Luxembourg [STATEC], 2014). 


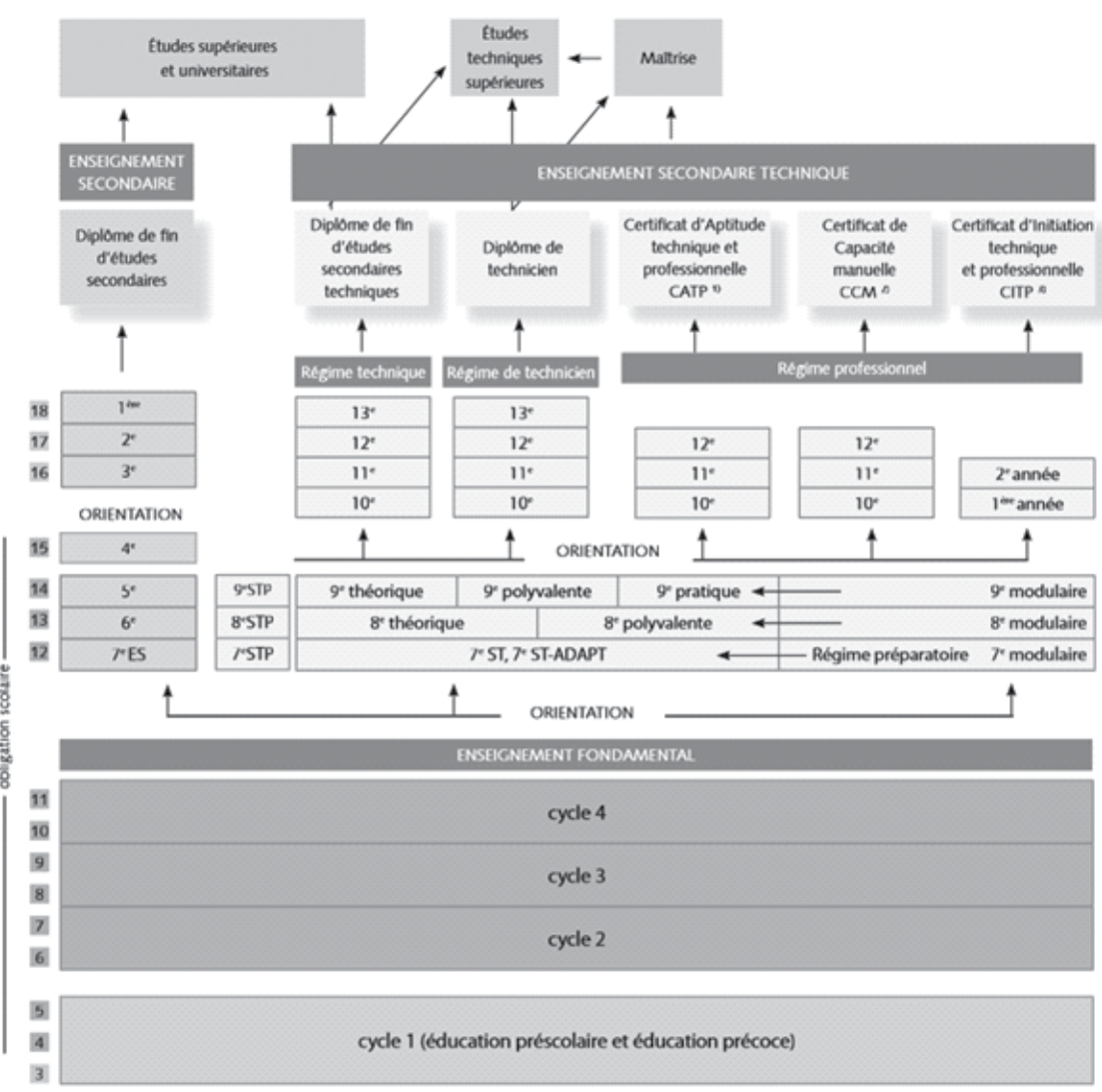

Figure 1: The Luxembourgish secondary school system in its official structure (school-year 2009/2010), (MENFP, 2011)

On an organisational level, the stratified Luxembourgish secondary school system consists of schools which combine academic, technical and vocational tracks, as well as schools that are specialised for either the technical track or the academic track (Backes, 2018). While the track selection at the transition point from primary to secondary school (vertical permeability) is highly regulated, the degree of legal regulations for track changes (passerelles) regarding parallel tracks during lower secondary education varies. Transitions within the technical secondary tracks (EST) between grade 7 and grade 9 are less regulated and the formulation of legal regulations is rather vague: besides remaining in the same track, transition towards more demanding as well as less demanding tracks are possible, as stated in the legal regulations. In general, the head of secondary schools owns a wide scope for decision-making on admissions by 
portfolio review (sur dossier), that means admissions based on alternative proof of suitability rather than official certificates (Backes, 2018). The institutionalised orientation phase after grade 9 is highly formalised, whereas transitions towards less demanding tracks mostly do not prescribe particular conditions. Remaining on the same track demands meeting certain achievement thresholds (minimum school marks) and sometimes additional qualifications depending on the envisioned destination track and vocational section. According to Luxembourg's school law, upward transitions after grade 9 in the technical tracks (EST) are at some point possible, but not strongly promoted; though one exception involves an integrational movement from the vocational track (préparatoire) towards the technical tracks (EST), which is made possible once students reach prescribed achievement levels and are willing to repeat the same grade in the more demanding track. According to previous studies, which made a distinction only between the academic secondary track (ES) as the highest track and the whole group of technical tracks (EST), permeability in Luxembourg is very low and mostly downwards (Schaltz \& Klapproth, 2014). Legally, upward transitions coming from the technical track and changing to the academic track across the EST-ES-borderline - are open to any student showing an averaged school mark of above 45 points (out of 60). Nevertheless, this transition option is not promoted in the official information brochures for students (MENFP, 2012). As already indicated, the idea of permeable educational tracks was not an important issue in Luxembourgish educational debates so far. Instead, this idea faded away with the decommissioned comprehensive reform proposals in the late 1970s (Schreiber, 2014). Since the topic is recently coming up again in public and political debates (MENFP, 2013) ${ }^{1}$, this study attempts to gain further understanding on the issue of permeability and its consequences in the context of Luxembourg.

In order to provide a differentiated and holistic picture of students' pathways through the Luxembourgish secondary schooling - employing a rather unconditional perspective on the overall contribution of intra-secondary mobility to inequality in final attainment -, we will present results of a cluster analysis of secondary school students' pathways, dealing with research question 1): How can students' pathways through Luxembourg's educational system be characterised and how do these types vary depending on social origin, gender and migration background? This is followed by analyses of particular points in the educational system of Luxembourg (hotspots) focusing on the specific mechanisms that explain differences in track change behaviour between different student groups by including school marks in the analyses (Boudon 1974). These hotspot analyses deal with question 2): What are the mechanisms behind track changes and does the use of track changes rather increase or decrease educational inequalities? 


\section{Method}

In order to generate a typology of educational pathways through the secondary school system of Luxembourg, a cluster analysis has first been carried out. As a second step, we examined educational inequalities by analysing the associations between students' social origins, genders and immigrant backgrounds and certain types of pathways (stable pathways versus pathways characterised by certain transitions between parallel school tracks). Drawing on our theoretical assumptions borrowed from Boudon (1974), the study aims to identify mechanisms behind transition behaviour. Thus, we looked at selected branching points (hotspots) and included students' achievement in stepwise logistic regression models in order to detect secondary effects. All calculations were done with IBM SPSS19 and ClustanGraphics8.

Database of the study is an administrative panel dataset (fichier élèves) of all 5301 students born in 1990 who were registered at a secondary school in Luxembourg for at least one school year. To analyse the different types of educational pathways, the sample was reduced to 3375 students who started secondary schooling in grade 7 in Luxemburg and also finished one of the secondary schooling pathways in Luxembourg. The difference in sample size is mainly due to school drop-outs and re-migration into countries of origin. Since every student in Luxembourg has a social security identification number (matricule), the dataset enabled us to follow the anonymous students through their entire secondary school career. Additionally, PISA 2006 data was matched with this administrative data set to be able to consider further socio-economic context variables. ${ }^{2}$

In regard to the axes of inequality under consideration, the operationalisation of the students' social origin was based on the parents' highest occupational status, which can be theorised as a mediator between educational attainment and income comprising of social capital (Baumert \& Maaz, 2006). According to Ganzeboom and Treiman (1996), the highest occupational status of the parents was measured in PISA 2006 via the ISEI-index (International Socio Economic Index), ranging from 16 (low) to 90 (high status). For better conceptual clarity of the calculated regression models (Hillmert \& Jacob, 2010), we classified the highest parental ISEI (father or mother; HISEI) in three categories (low: 16 to 33 , medium: 34 to 51 , high: 52 to 90) based on the categorisation used in previous Luxembourg-specific studies on the link between school competencies and social origin (MENFP \& Educational Measurement and Applied Cognitive Science [EMACS], 2007). Conceptually, the three groups correspond to the following categories of the EGP class scheme (Erikson, Goldthorpe \& Portocarero, 1979): HISEI low relates to semi- and unskilled manual workers (EGP VII); HISEI medium relates to routine non-manual, lower-sales service, manual supervisors and skilled manual workers (EGP III-VI); HISEI high relates to the service classes (EGP I+II). Most of the students (cohort 1990) completing their 
secondary schooling in Luxembourg originate from the highest HISEI group (43\%), 36 per cent from the middle category and 21 per cent from the low status group. For 10 per cent of the students, no information on HISEI is available and, thus, multiple imputation is applied. ${ }^{3}$ Gender was measured as a dichotomous variable. The number of female students $(52 \%)$ slightly exceeds the number of male students ( $48 \% ; \mathrm{n}=3375) .{ }^{4}$ In order to analyse the students' migration background, the primary language spoken at home was used to make distinctions between different immigrant groups by taking into account findings showing that migrants are not disadvantaged solely by their migration background. Indeed, while some ethnic groups perform like natives, migrant groups from certain countries experience disadvantages more often linked to their socio-structural position (Hadjar et al., 2015). Furthermore, language spoken at home mirrors to some extent socio-cultural background and cultural practices in the family (Kristen \& Granato, 2007). The 54 different languages spoken at home were classified in three categories: (a) Luxembourgish or German as proxy for natives, (b) Balkan or Portuguese as "vulnerable migrant groups»5 (Griga \& Hadjar, 2013, p. 499) and (c) other languages. According to this classification 72 per cent of the 3375 students speak primarily Luxembourgish/German at home, 17 per cent belong to the vulnerable migrant groups and 11 per cent to other languages. Missing data concerns less than 1 per cent of the cases.

For the measure of educational achievement, the students' school marks were used, averaged and weighted by the Ministry of education according to the track specific regulations. School marks in Luxembourg range from 1 (worst) to 60 (best).

By creating variables regarding school tracks, such as orientation after primary school or intra-secondary transitions, we ensure the highest possible degree of differentiation. Whereas previous studies in Luxembourg only looked at changes between academic secondary track (ES) and technical secondary track (EST), we also included transitions within the subdivided technical tracks (EST) that include both technical general secondary tracks and vocational tracks (e.g., changes between pratique and polyvalente; cf. figure 1). Thus, we defined intra-secondary transition as a change from the current school track to a track that does not correspond to the same ability level (niveau scolaire). This level is measured by (inter)national competence tests in grade 9 which clearly show that competences (in math, science and reading) of students of the academic secondary track (ES) are higher than those of the students in technical secondary tracks (EST) (MENFP \& EMACS, 2007). Our own calculations combining the administrative data with PISA data confirm this achievement distribution for sub-tracks within the technical secondary education (EST); théorique-students perform better than polyvalente-students which outperform pratique-students as well as préparatoire-students leading to the following coding: transitions towards more vocation-oriented tracks - in figure 1 to the right - are defined as downward transitions to an in average less demanding track (experienced by 38 
per cent of the 3375 students) and transitions to the left are defined as upward transitions (experienced by 13 per cent). ${ }^{6}$

\section{Results}

First, the procedure and results of the cluster analysis of educational pathways will be presented. Then, systematic variations in the different pathway types will be looked at in terms of educational inequalities. Finally, logistic regression models in regard to inequalities at selected branching points in the Luxembourgish education system (hotspots) will illuminate the mechanisms behind (re-)orientations.

\section{Typology of educational pathways through secondary schooling}

The aim of a cluster analysis is to generate a typology by sorting people in a way that the similarity between two people is maximal if they belong to the same group and minimal otherwise. For that purpose, we included track orientation after primary school (academic track, technical track, vocational track), intra-secondary track changes (within lower and upper secondary education; between grade 7 and grade 13) and temporary pathway interruptions as cluster variables ${ }^{7}$ in the analysis based on data of $3372^{8}$ secondary school careers that started and ended in Luxembourg. In order to detect the optimal number of types, a hierarchical cluster analysis was employed (ward linkage procedure), followed by a k-Means analysis for refining the attribution of individuals to types. The results revealed eight types (see table 1). ${ }^{9}$

Table 1: Typology of secondary school students' pathways through secondary schooling in Luxembourg

\begin{tabular}{|l|l|l|}
\hline Type 1 & ES immobile pathways & $\mathrm{n}=1259$ \\
\hline Type 2 & ES downwardly mobile pathways & $\mathrm{n}=237$ \\
\hline Type 3 & Upwardly mobile pathways to the ES & $\mathrm{n}=63$ \\
\hline Type 4 & EST internal upward and multi-mobile pathways & $\mathrm{n}=144$ \\
\hline Type 5 & EST immobile pathways & $\mathrm{n}=564$ \\
\hline Type 6 & EST downwardly mobile pathways & $\mathrm{n}=705$ \\
\hline Type 7 & EST upwardly mobile pathways with integrational movements & $\mathrm{n}=212$ \\
\hline Type 8 & Interrupted pathways & $\mathrm{n}=188$ \\
\hline
\end{tabular}

Cluster 1 relates to a stable academic pathway (ES immobile). This is the largest group with 1259 students who attended the academic secondary track (ES) throughout their secondary schooling career. Cluster 2 relates to downwardly 
mobile pathways from the academic secondary track (ES) towards one of the technical secondary schooling tracks (EST). This cluster includes 237 students who started in the academic track and left it early to continue in a technical track. Cluster 3 relates to upwardly mobile students who entered the academic secondary track (ES) later on. Only 63 students belong to this type that involves a crossing of the border between technical secondary education and the academic secondary education. Cluster 4 groups 144 students who experienced at least one upward change within the technical tracks (EST). Cluster 5 relates to stable pathways within the technical secondary tracks (EST) and gathers 564 students who remained immobile in their technical secondary tracks. Cluster 6 contains students who moved downwards within the technical tracks (EST). A substantial number of 705 students followed this pathway. Cluster 7 consists of students who started in the vocational track (préparatoire) and managed an upward change into the technical EST tracks (212 students). The last type is the most heterogeneous cluster consisting of pathways that were interrupted at least once (188 students).

\section{Educational inequalities in educational pathways}

In order to study the social selectiveness of particular pathway types, and thus, to analyse educational inequalities, the different pathway types evolving from the cluster analysis were compared in accordance to students' socio-economic status (HISEI), gender and immigrant background (language spoken at home) (for detailed results, see Backes, 2018). As hypothesised, social origin is an important predictor of the pathways followed after the transition to secondary school. The parental status works especially well as a discriminator between pathways which cross the «academic borderline»; the likelihood to experience downward mobility from the academic track $(E S)$ - compared to the reference category of remaining in the academic ES track - is significantly higher for students from lower social origin than for high SES students. Likewise, upwardly mobile pathways towards the academic track (ES) are more likely for a student originating from a privileged SES background. Gender also predicts the continuation of a career in the academic ES track: female students are more likely to stay on the academic track (ES) than male students. This holds also true for transitions within the technical EST tracks. Male students more often follow downwardly mobile pathways within the technical and vocational EST tracks. Regarding the migration background, the data are consistent with our hypotheses. The ethnic effect varies according to the countries of origin. Portuguese and Balkan migrants are more likely to leave the academic ES track early, whereas they are less likely to move downwards within the technical EST tracks. Other migrant groups, such as English and French speaking children, are more likely to enter the academic ES track via intra-secondary transitions. 


\section{Hotspot analyses}

In line with Boudon (1974), it is worthwhile to include the students' school marks into the analysis of educational transitions in order to identify secondary effects along the inequality axes of interest. Thus, we analysed selected points (hotspots) and included school marks in the stepwise regression models. School marks are preferred over competences, because they are more relevant when it comes to transition decisions than factual competencies (Hadjar et al., 2015). Logistic regressions display odds ratios ${ }^{10}$ which indicate how the likelihood to make an upward or downward transition differs between particular student groups. ${ }^{11}$

Table 2: Predictor variables for early transitions after grade 7 in the academic track (ES)

Reference category: remaining in academic track ES (regular transition from $7^{\text {th }}$ grade academic ES to $\mathbf{8}^{\text {th }}$ grade academic ES)

\begin{tabular}{|c|c|c|c|c|c|c|}
\hline $\begin{array}{l}\text { odds ratios }(\operatorname{Exp}(\mathrm{B})) \\
{[95 \% \text {-confidence }} \\
\text { interval }]\end{array}$ & \multicolumn{2}{|c|}{$\begin{array}{l}\text { model } 1 \\
\text { downwards to EST }\end{array}$} & \multicolumn{2}{|c|}{$\begin{array}{l}\text { model } 2 \\
\text { downwards to EST }\end{array}$} & \multicolumn{2}{|c|}{$\begin{array}{l}\text { model } 3 \\
\text { downwards to EST }\end{array}$} \\
\hline $\begin{array}{l}\text { gender male } \\
\text { ref. female }\end{array}$ & 1.19 & {$[0.75 ; 1.88]$} & 1.27 & {$[0.79 ; 2.01]$} & $0.45^{*}$ & {$[0.23 ; 0.90]$} \\
\hline $\begin{array}{l}\text { vulnerable migrant } \\
\text { group }\end{array}$ & $3.48^{* * *}$ & {$[1.93 ; 6.29]$} & $2.42^{*}$ & {$[1.18 ; 4.95]$} & 0.42 & {$[0.14 ; 1.27]$} \\
\hline $\begin{array}{l}\text { other migrant groups } \\
\text { ref. lux-german }\end{array}$ & 1.50 & {$[0.73 ; 3.11]$} & 1.41 & {$[0.68 ; 2.93]$} & 0.87 & {$[0.31 ; 2.42]$} \\
\hline $\begin{array}{l}\text { social origin low } \\
\text { (HISEI) }\end{array}$ & & & 2.27 & {$[0.99 ; 5.20]$} & 1.82 & {$[0.51 ; 6.46]$} \\
\hline $\begin{array}{l}\text { social origin medium } \\
\text { (HISEI) } \\
\text { ref. Social origin high } \\
\text { (HISEI) }\end{array}$ & & & $2.12^{* *}$ & {$[1.24 ; 3.63]$} & 1.91 & {$[0.94 ; 3.91]$} \\
\hline school mark (averaged) & & & & & $0.50^{* * *}$ & {$[0.44 ; 0.57]$} \\
\hline $\begin{array}{l}\text { Constant } \\
\text { Nagelkerke's R² } \\
\mathrm{N}\end{array}$ & $\begin{array}{l}-3.35^{* * *} \\
0.028 \\
1715\end{array}$ & & $\begin{array}{l}-3.70^{* * *} \\
0.045 \\
1715\end{array}$ & & $\begin{array}{l}23.71^{* * *} \\
0.633 \\
1715\end{array}$ & \\
\hline
\end{tabular}

${ }^{*} \mathrm{p}<0.05,{ }^{* *} \mathrm{p}<0.01,{ }^{* * *} \mathrm{p}<0.001$

Frequencies: Remaining in academic track: $95.5 \%$; Downward change to technical track: $4.5 \%$; Binary logistic regression, own calculations, data source: fichier élèves 
Early re-orientations: track changes after the first year of secondary education. Table 2 shows the first hotspot referring to transitions after grade 7 in the academic track (ES). As model 1 clearly shows, the likelihood of leaving the academic track early is more than three times higher for vulnerable migrant groups than for natives. Controlled for social origin (model 2), this effect slightly decreases. Furthermore, there is a genuine effect of parental status on the likelihood of this transition: low and medium SES students leave the academic track (ES) about two times more likely than SES advantaged students.

Table 3a: Predictor variables for early transitions after grade 7 in technical track (EST) towards academic track (ES)

Reference category: remaining in the same school track (regular transition from $7^{\text {th }}$ grade technical ST to $8^{\text {th }}$ grade technical théorique)

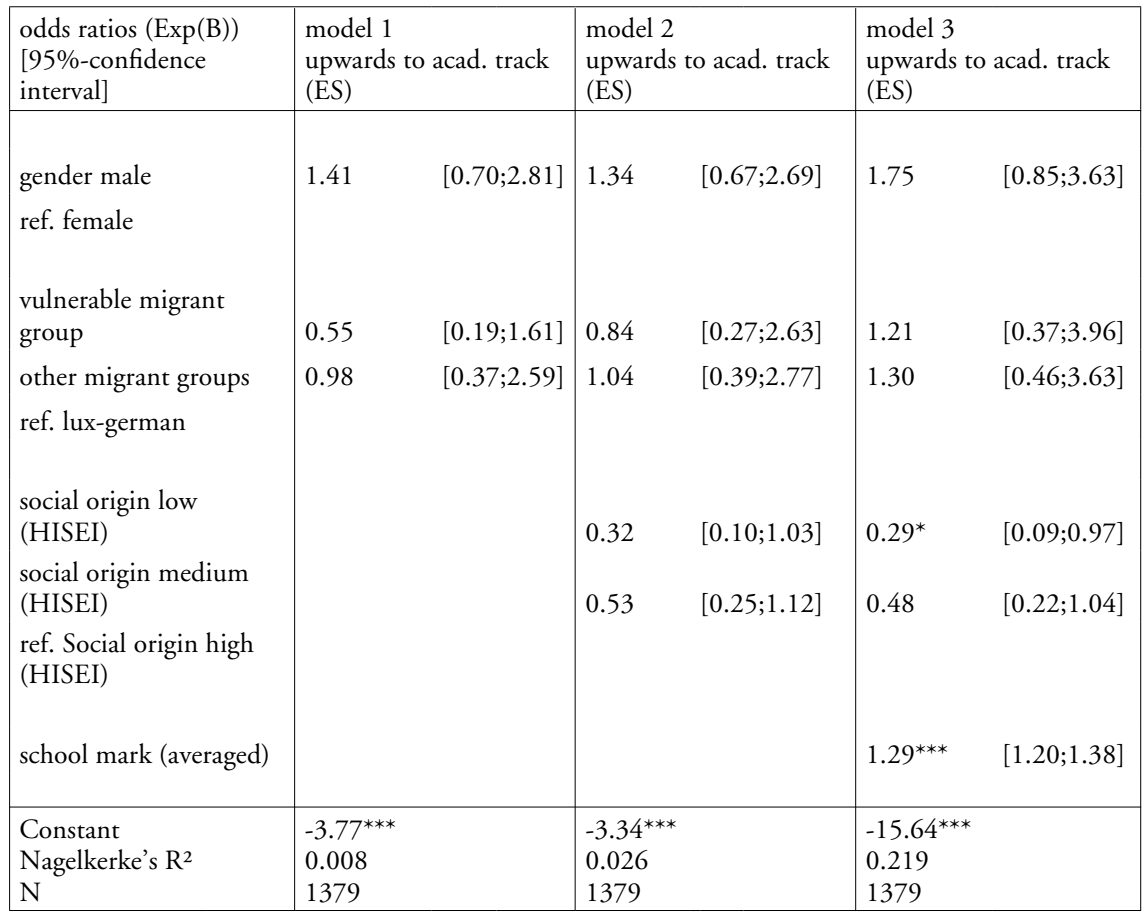

${ }^{*} \mathrm{p}<0.05,{ }^{* *} \mathrm{p}<0.01,{ }^{* * *} \mathrm{p}<0.001$

Frequencies: Remaining in technical track: $97.5 \%$; Upward change to academic track: $2.5 \%$;

Binary logistic regression, own calculations, data source: fichier élèves 
Table 3b: Predictor variables for early transitions after grade 7 in technical track (EST) towards less demanding tracks (polyvalente, préparatoire)

Reference category: remaining in the same school track (regular transition from $7^{\text {th }}$ grade technical $S T$ to $8^{\text {th }}$ grade technical théorique)

\begin{tabular}{|c|c|c|c|c|c|c|}
\hline $\begin{array}{l}\text { odds ratios }(\operatorname{Exp}(\mathrm{B})) \\
{[95 \% \text {-confidence }} \\
\text { interval] }\end{array}$ & \multicolumn{2}{|c|}{$\begin{array}{l}\text { model } 1 \\
\text { downwards to polyva- } \\
\text { lente or préparatoire }\end{array}$} & \multicolumn{2}{|c|}{$\begin{array}{l}\text { model } 2 \\
\text { downwards to polyva- } \\
\text { lente or préparatoire }\end{array}$} & \multicolumn{2}{|c|}{$\begin{array}{l}\text { model } 3 \\
\text { downwards to polyva- } \\
\text { lente or préparatoire }\end{array}$} \\
\hline $\begin{array}{l}\text { gender male } \\
\text { ref. female }\end{array}$ & 1.13 & {$[0.87 ; 1.47]$} & 1.15 & {$[0.89 ; 1.48]$} & 0.74 & {$[0.51 ; 1.08]$} \\
\hline $\begin{array}{l}\text { vulnerable migrant } \\
\text { group }\end{array}$ & $1.50^{* *}$ & {$[1.11 ; 2.02]$} & 1.37 & {$[0.99 ; 1.89]$} & $0.58^{*}$ & {$[0.36 ; 0.95]$} \\
\hline $\begin{array}{l}\text { other migrant groups } \\
\text { ref. lux-german }\end{array}$ & 0.80 & {$[0.53 ; 1.21]$} & 0.78 & {$[0.51 ; 1.19]$} & $0.45^{* *}$ & {$[0.25 ; 0.81]$} \\
\hline $\begin{array}{l}\text { social origin low } \\
\text { (HISEI) }\end{array}$ & & & $1.53^{*}$ & {$[1.02 ; 2.31]$} & 1.58 & {$[0.83 ; 2.83]$} \\
\hline $\begin{array}{l}\text { social origin medium } \\
\text { (HISEI) } \\
\text { ref. Social origin high } \\
\text { (HISEI) }\end{array}$ & & & $1.67^{* *}$ & & $1.66^{*}$ & {$[1.01 ; 2.73]$} \\
\hline school mark (averaged) & & & & & $0.60^{* * *}$ & {$[0.56 ; 0.64]$} \\
\hline $\begin{array}{l}\text { Constant } \\
\text { Nagelkerke's R² } \\
\mathrm{N}\end{array}$ & $\begin{array}{l}-1.66^{* * *} \\
0.010 \\
1635\end{array}$ & & $\begin{array}{l}-2.01^{* * *} \\
0.020 \\
1635\end{array}$ & & $\begin{array}{l}-18.37^{*} \\
0.645 \\
1635\end{array}$ & \\
\hline
\end{tabular}

${ }^{*} \mathrm{p}<0.05,{ }^{* *} \mathrm{p}<0.01,{ }^{* * *} \mathrm{p}<0.001$

Frequencies: Remaining in technical track: $82.2 \%$; Downward change to polyvalente, préparatoire: 17.8 $\%$; Binary logistic regression, own calculations, data source: fichier élèves

Finally, model 3 reveals that there are neither secondary effects of social origin nor ethnic secondary effects, but secondary gender effects. Controlling for primary effects (school marks), male students are less likely to leave the academic track and experience downward mobility than female students. This is perhaps due to effects of clemency that teachers show vis-à-vis the well-known gender-achievement gap in favour of female students in secondary education.

The second hotspot (regarding early track changes) shows to what extent socio-economic student characteristics have an impact on transitions from the technical tracks (EST) after grade 7. In Table 3a, the likelihood of an upward movement to the academic track (ES) (reference category: staying on the same technical EST track) is analysed. The regression reveals that secondary effects also play a role for early upward mobility from the technical secondary track 
(EST) towards the academic track (ES). Controlled for school marks (model 3), parental occupational status still has an impact. Even under the assumption that students achieve the same marks, students from lower social background are less likely to shift to the academic track (EST). Table $3 \mathrm{~b}$ compares changing towards less demanding tracks within the technical EST (reference category: remaining in the current track). Looking at model 3, secondary effects of social origin appear as well as secondary effects of migration background. Students of «vulnerable migration backgrounds» (Portuguese or Balkan origin) are less likely to move downwards than natives. This indicates the positive secondary effect of migration, because these migrant groups are actually more likely to move downwards if achievement is not controlled for (model 2).

Re-orientations in the official orientation phase after lower secondary schooling. The first selected hotspot is the grade 9 théorique track within the technical tracks (EST), situated within the institutionalised orientation phase. Remaining in the same track - théorique prepares for the highest possible degree within the technical tracks (EST) - requires fulfilling certain criteria with regard to school marks. Changing upwards to the academic track (ES) is legally possible but not promoted. From an inequality perspective, this hotspot is meaningful, since changing downwards towards vocational tracks starting in grade 10 (see figure 1) implies that no direct entrance into university will be possible, a fact which might influence later life chances.

The odds ratios in model 1 to 3 (Table 4a) illustrate the social selectivity of students who cross the educational borderline to the academic track: female students and privileged migrants (that is to say, non-Balkan and non-Portuguese backgrounds) have a higher tendency to make a transition towards the academic track (ES). Controlled for school marks, different patterns come into light. With regard to gender, only primary effects impact upward changes in comparison to staying in the comparably lower track. Controlling for achievement, male students do not differ in transitions after grade 9 théorique (the highest of the technical tracks/EST). On the other hand, secondary effects of social origin (to the advantage to high SES students) and secondary effects of migration background (to the advantage of other language groups) occur if achievement is controlled for (model 3). Examining the factors that influence a downward change towards vocational tracks (Formation Technicien, CATP; reference: remaining in théorique track; Table $4 \mathrm{~b}$ ), effects regarding all the axes of inequality analysed can be identified. Students of lower social origin are more likely to change downwards. At this branching point, also male students change more often towards vocational tracks even under control of achievement. Migrants - vulnerable migrant groups as well as other language groups are less likely to transit to vocational tracks at this hotspot. 
Table 4a: Predictor variables for transitions in offcial orientation phase after grade 9 from highest technical track (théorique) towards academic track (ES)

Reference category: remaining in the same school track (regular transition from $9^{\text {th }}$ grade technical théorique to $10^{\text {th }}$ grade technical Régime technique)

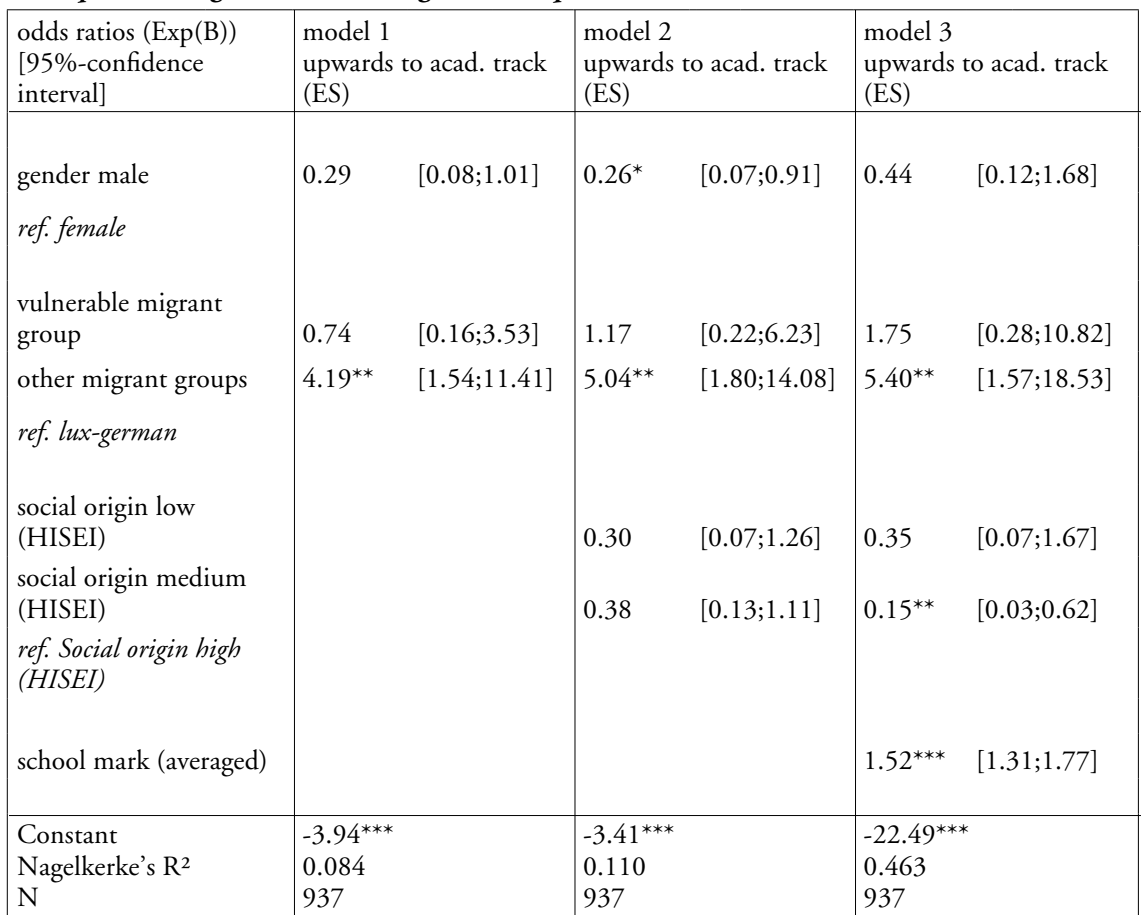

${ }^{*} \mathrm{p}<0.05,{ }^{* *} \mathrm{p}<0.01,{ }^{* * *} \mathrm{p}<0.001$

Frequencies: Remaining in highest technical secondary track EST théorique: $98.1 \%$; Upward change to academic track (ES): $1.9 \%$; Binary logistic regression, own calculations, data source: fichier élèves

The official orientation phase after lower secondary schooling in the academic track (ES) takes place after grade 10. The analysis of the factors that influence leaving the academic track (ES) towards technical tracks (EST) after grade 10 (tables not reported here) indicates no migration-specific differences and no socially-selective transitions anymore. However, there is a gender effect: Male students leave the academic track (ES) after grade 10 two times more often than female students do due to their lower achievement. Taking their school marks into account, there are no indications for gender-specific secondary effects anymore.

In sum, the hotspot analyses regarding educational inequalities showed that in the academic track (ES) natives, high SES-students and female students are advantaged. This is particularly owed to primary effects, specifically their higher achievements. 
Table 4b: Predictor variables for transitions in offcial orientation phase after grade 9 from highest technical track (théorique) towards vocational tracks (Formation Technicien/FT or CATP)

Reference category: remaining in the same school track (regular transition from $9^{\text {th }}$ grade théorique to $10^{\text {th }}$ grade Régime technique)

\begin{tabular}{|c|c|c|c|c|c|c|}
\hline $\begin{array}{l}\text { odds ratios }(\operatorname{Exp}(B)) \\
{[95 \% \text {-confidence }} \\
\text { interval] }\end{array}$ & \multicolumn{2}{|c|}{$\begin{array}{l}\text { model } 1 \\
\text { downwards to FT or } \\
\text { CATP }\end{array}$} & \multicolumn{2}{|c|}{$\begin{array}{l}\text { model } 2 \\
\text { downwards to FT or } \\
\text { CATP }\end{array}$} & \multicolumn{2}{|c|}{$\begin{array}{l}\text { model } 3 \\
\text { downwards to FT or } \\
\text { CATP }\end{array}$} \\
\hline $\begin{array}{l}\text { gender male } \\
\text { ref. female }\end{array}$ & $2.60^{* * *}$ & [2.04;3.33] & $2.67^{* * *}$ & [2.08;3.41] & $2.83^{* * *}$ & {$[2.09 ; 3.83]$} \\
\hline $\begin{array}{l}\text { vulnerable migrant } \\
\text { group } \\
\text { other migrant groups } \\
\text { ref. Iux-german }\end{array}$ & $\begin{array}{l}0.77 \\
0.59^{* *}\end{array}$ & $\begin{array}{l}{[0.56 ; 1.05]} \\
{[0.40 ; 0.88]}\end{array}$ & $\begin{array}{l}0.65^{*} \\
0.56^{* *}\end{array}$ & $\begin{array}{l}{[0.46 ; 0.92]} \\
{[0.38 ; 0.84]}\end{array}$ & $\begin{array}{l}0.47^{* * *} \\
0.42^{* * *}\end{array}$ & $\begin{array}{l}{[0.31 ; 0.72]} \\
{[0.26 ; 0.68]}\end{array}$ \\
\hline $\begin{array}{l}\text { social origin low } \\
\text { (HISEI) } \\
\text { social origin medium } \\
\text { (HISEI) } \\
\text { ref. Social origin high } \\
\text { (HISEI) }\end{array}$ & & & $\begin{array}{l}1.51^{*} \\
1.16\end{array}$ & $\begin{array}{l}{[1.05 ; 2.17]} \\
{[0.86 ; 1.56]}\end{array}$ & $\begin{array}{l}1.61^{*} \\
1.08\end{array}$ & $\begin{array}{l}{[1.03 ; 2.52]} \\
{[0.76 ; 1.54]}\end{array}$ \\
\hline school mark (averaged) & & & & & $0.67^{* * *}$ & {$[0.64 ; 0.71]$} \\
\hline $\begin{array}{l}\text { Constant } \\
\text { Nagelkerke's } \mathrm{R}^{2} \\
\mathrm{~N}\end{array}$ & $\begin{array}{l}-1.23^{* * *} \\
0.075 \\
1318\end{array}$ & & $\begin{array}{l}-1.37^{* * *} \\
0.081 \\
1318\end{array}$ & & $\begin{array}{l}14.41^{* * *} \\
0.389 \\
1318\end{array}$ & \\
\hline
\end{tabular}

${ }^{*} \mathrm{p}<0.05,{ }^{* *} \mathrm{p}<0.01,{ }^{* * *} \mathrm{p}<0.001$

Frequencies: Remaining in highest technical track EST théorique: $69.8 \%$; Downward change to vocational track: $30.2 \%$; Binary logistic regression, own calculations, data source: fichier élèves

Within the technical tracks (EST), disadvantages can be stated for low SES-students, who are less likely to move upwards and at some hotspots or points more likely to move downwards. This may be explained by the fact that staying on the actual track is sufficient to maintain the parental status (Becker, 2003). In terms of gender, male students are more likely to move towards vocational tracks within the orientation phase after grade 9, which may be explained by occupational choices that are influenced by traditional gender role perceptions. As regards Portuguese and Balkan students, positive secondary effects appear at some branching points. This is in line with the assumption that migrants show a high degree of motivation. 


\section{Conclusions}

The main objective of this study was to contribute to the debate on an inequality-reducing function of permeability in stratified education systems, since permeability is assumed to give students a chance to be re-orientated during secondary schooling. In Luxembourg, longitudinal analyses of educational trajectories and intra-secondary transitions are rare so far. This study provides a holistic picture of students' secondary pathways by conducting a cluster analysis which revealed eight types of trajectories. Briefly put, a large part $(46 \%)$ of the students experienced (multiple) broken pathways. Most of the technical tracks (EST) internal pathways included compensatory or accumulated events. So called "smooth transitions," which, according to Herlihy (2007, p. 1), relate to lower dropout rates and prevent a loss of motivation, are normality for most of academic students (ES), whereas this is much less the case for students in technical/vocational tracks.

From an inequality perspective, both the cluster and hotspot analyses showed that social origin, gender and migration background play a crucial role in the placement gaps and track change behaviour. The mechanisms underlying different transition patterns vary between branching points and student groups in terms of achievement-related and decision-related effects. Empirical results suggest that track changes mirror the transition patterns at the first orientation phase. Already advantaged students benefit most from re-orientations: While students of lower social origin and male students are more likely to experience immobile careers in lower tracks and downwardly mobile pathways, students from higher social origin and female students are more likely to follow immobile academic careers and upwardly mobile pathways. As regards migration background, the patterns depend on language groups and branching points: migrant-specific disparities increased in the academic track (ES) and decreased in the technical tracks (EST) through upwardly mobile pathways and higher continuity rates of students with migration backgrounds (controlled for achievement); whereas in the case of vulnerable migrant groups, this decreasing effect did not concern re-orientations to the highest tracks that are required for a direct entrance into university. Thus, the «lived» permeability in Luxembourg partly decreases, but mainly reproduces disparities in track placement, since crucial «educational barriers» between tracks are rather solid and the vast majority of «border crossers» experiences downward transitions.

With regard to limitations of this study, a main issue is the lack of certain data such as post-secondary pathways and language resources. Due to small numbers of students that experience transitions between parallel tracks (in terms of «horizontal» or «intra-secondary» transitions), the presented coefficients must be interpreted with caution. A further limitation concerns the sample reduction for the typology of secondary pathways, resulting in a sample bias: male students, low SES students and migrants are underrepresented in the cluster sample since 
they more often experience drop-out before graduating. Due to the focus on complete secondary pathways and the additional hotspot analyses with the full sample, this limitation is acceptable, but further studies should address the discontinued trajectories of drop-out students.

If we consider the structure of the Luxembourgish education system, the consequences of these results for the education system become obvious. As existing permeability between tracks is selectively used - as results have shown -, permeability in this form does not seem to be able to dissolve the stratification-inequality-link. On the other hand, abolishing permeable structures between tracks would cause an even earlier and more stable determination of students' trajectories. Thus, the current arrangement of the education system must be put into question in the light of claiming educational equality. Intended and unintended consequences of the first structural adjustments to be undertaken - as the more comprehensive PROCI project - remain to be researched in the future.

\section{Notes}

1 The pilot project PROCI involves comprehensive schooling of the technical tracks from grade 7 to grade 9 in order to decrease repetition rates.

2 The descriptive statistics presented below relate to the 3375 students in the longitudinal sample that is used for the cluster analysis in regard to types of educational pathways.

3 Beside the model variables auxiliary variables were included in the multiple imputation (e.g., parental occupational surveyed by the Ministry of education). A detailed description of the imputation process and the plausibility checks can be requested from the first author.

4 The uneven distribution can be attributed to a sample bias. Since boys, migrants and working class students more often leave Luxembourg's secondary schools before graduating, girls, high SES students and natives are overrepresented in the longitudinal data set that is used for the typology of secondary school students' pathways.

5 Vulnerable migrant groups share a disadvantaged class position. Furthermore, they face «vulnerable educational situations» (Gomensoro \& Bernardi, 2015, p. 2) such as higher repetition rates and placement in lower tracks, and might experience stigmatisation.

6 An additional variable for characterising pathways is interruption. An interruption experienced by 8 percent of the students - means that a student was not attending an official secondary school for at least one year within secondary schooling (e.g., due to illness, school absenteeism, stay abroad, temporary transition to working life).

7 Since scale levels differ, variables were transformed, standardised and weighted (Bacher, Pöge \& Wenzig, 2010).

8 Three outliers were excluded.

9 Validity of cluster analysis cannot be expressed in fit indices. Thus, a range of stability tests was conducted, for example tree validation via permutation, focal point analyses, split-half method, F-tests, discriminatory analyses, cross validation after model specification as well as content and theoretical validity checks, all of which approving a good cluster solution.

10 Since we interpret direction and significance of influences, but do not compare effects related to different samples, we stick to the well-established odds ratios in inequality research (Breen \& Goldthorpe, 1999; Schindler, 2015). Furthermore, we carried out extensive validation checks for all models presented on the basis of average marginal effects and found no difference between odds ratios and average marginal effects regarding the direction of the effects. 
11 In regard to certain transitions between parallel school tracks, the number of students is very low (e.g., transition from technical track EST-théorique towards academic track). The fact that in regard to random sample studies, such analyses were "on the edge," is not a problem for our analysis of census data (so to speak, all people who experienced a certain hotspot are included). Considering the debate on the usefulness of inference statistics for the analysis of census data, we follow Broscheid and Gschwend (2005) and report confidence intervals (and even mention significance levels), but also stress that these parameters are of less importance for the following analysis.

\section{References}

Backes, S. (2018). Heterogenität im luxemburgischen Schulsystem - Eine Mixed-Method-Studie $z u$ Bildungsverläufen aus ungleichheitstheoretischer Perspektive. Weinheim: Beltz.

Bacher, J., Pöge, A. \& Wenzig, K. (2010). Clusteranalyse: Anwendungsorientierte Einführung in Klassifikationsverfahren. München: Oldenbourg Verlag.

Baumert, J. \& Maaz, K. (2006). Das theoretische und methodische Konzept von PISA zur Erfassung sozialer und kultureller Ressourcen der Herkunftsfamilie. In J. Baumert, P.

Stanat \& R. Watermann (Éd.), Herkunftsbedingte Disparitäten im Bildungswesen: Differenzielle Bildungsprozesse und Probleme der Verteilungsgerechtigkeit; vertiefende Analysen im Rahmen von PISA 2000 (pp. 11-30). Wiesbaden: VS Verlag für Sozialwissenschaften.

Becker, R. (2003). Educational expansion and persistent inequalities of education utilizing subjective expected utility theory to explain increasing participation rates in upper secondary school in the Federal Republic of Germany. European sociological review, 19, (1), 1-24.

Becker, R. (2014). Reversal of gender differences in educational attainment historical analysis of the West German case. Educational research, 56, (2), 184-201.

Becker, R. \& Schubert, F. (2011). Die Rolle von primären und sekundären Herkunftseffekten für Bildungschancen von Migranten im deutschen Schulsystem. In R. Becker (Éd.), Integration durch Bildung (pp. 161-194). Wiesbaden: VS Verlag.

Becker, R. \& Müller, W. (2011). Bildungsungleichheiten nach Geschlecht und Herkunft im Wandel. In A. Hadjar (Éd.), Geschlechtsspezifische Bildungsungleichheiten (pp. 55-75). Wiedbaden: VS Verlag.

Bellenberg, G. (2012). Schulformwechsel in Deutschland. Gütersloh: Bertelsmann Stiftung.

Boudon, R. (1974). Education, opportunity and social inequality: Changing prospects in Western society. New York, NY: Wiley.

Breen, R. \& Goldthorpe, J. H. (1999). Class inequality and meritocracy: A critique of Saunders and an alternative analysis. British journal of sociology, 50, (1), 1-27.

Broscheid, A. \& Gschwend, T. (2005). Zur statistischen Analyse von Vollerhebungen. Politische Vierteljahresschrift, 46, (1), O-16-O-26.

Cortina, K. S. (2003). Der Schulartwechsel in der Sekundarstufe I: Pädagogische Maßnahme oder Indikator eines falschen Systems? Zeitschrift für Pädagogik, 49, (1), 127-141.

Erikson, R., Goldthorpe, J. H. \& Portocarero, L. (1979). Intergenerational class mobility in three Western European societies: England, France and Sweden. British journal of sociology, 30, (4), 341-415.

Francis, B. (2000). Boys, girls, and achievement: Addressing classroom issues. London: Routledge Falmer.

Ganzeboom, H. B. G. \& Treiman, D. J. (1996). Internationally comparable measures of occupational status for the 1988 International Standard Classification of Occupations. Social science research, 25, (3), 201-239.

Gomensoro, A. \& Bernardi, L. (2015). Educational trajectories of the children of migrants in Switzerland. Paper presented at Population Association of America, San Diego, California. 
Griga, D. \& Hadjar, A. (2013). Inégalités de formation lors de l'accès à l'enseignement supérieur selon le sexe et le contexte migratoire: résultats de l'analyse des situations suisse, allemande et française. Revue suisse des sciences de l'éducation, 35, (3), 493-513.

Hadjar, A. \& Becker, R. (2011). Erwartete und unerwartete Folgen der Bildungsexpansion in Deutschland. In R. Becker (Éd.), Lehrbuch der Bildungssoziologie (pp. 203-222). Wiesbaden: VS Verlag.

Hadjar, A. \& Becker R. (2016). Education systems and meritocracy: Social origin, educational and status attainment. In A. Hadjar \& C. Gross (Éd.), Education systems and inequalities. International comparisons (pp. 231-258). Bristol: Policy Press.

Hadjar, A. \& Buchmann, C. (2016). Education systems and gender inequalities in educational attainment. In A. Hadjar \& C. Gross (Éd.), Education systems and inequalities. International comparisons (pp. 159-184). Bristol: Policy Press.

Hadjar, A., Fischbach, A., Martin, R. \& Backes, S. (2015). Bildungsungleichheiten im luxemburgischen Bildungssystem. In MEN \& Université du Luxembourg (Éd.), Bildungsbericht Luxemburg 2015: Analysen und Befunde (pp. 34-56). MEN und Université du Luxembourg, Luxembourg.

Hadjar, A. \& Rothmüller, B. (2016). Chancengleichheit und Leistungsmotiv in der Bildungspolitik: Die Debatten um die Gesamtschule am Beispiel Luxemburgs. OZP - Austrian Journal of Political Science, 45, (1), 51-64.

Herlihy, C. (2007). Toward ensuring a smooth transition into high school. Washington, DC: National High School Center.

Hillmert, S. \& Jacob, M. (2005). Zweite Chance im Bildungssystem? Zur sozialen Selektivität bei ,späteren' Bildungsentscheidungen. In P. A. Berger \& H. Kahlert (Éd.), Institutionalisierte Ungleichheiten: Wie das Bildungswesen Chancen blockiert (pp. 155-176). Weinheim: Juventa.

Hillmert, S. \& Jacob, M. (2010). Selections and social selectivity on the academic track: A life-course analysis of educational attainment in Germany. Research in social stratification and mobility, 28, (1), 59-76.

Jacob, M. (2004). Mehrfachausbildungen in Deutschland: Karriere, Collage, Kompensation? Wiesbaden: VS Verlag.

Jacob, M. \& Tieben, N. (2007). Social Selectivity of Track Mobility in Secondary Schools: A Comparison of Intra-secondary Transitions in Germany and the Netherlands. Mannheim: MZES. Retrieved from http://www.mzes.uni-mannheim.de/publications/wp/wp-105.pdf

Kao, G. \& Tienda, M. (1998). Educational aspirations of minority youth. American journal of education, 106, (3), 349-384.

Kemnade, I. (1989). Schullaufbahnen und Durchlässigkeit in der Sekundarstufe I: Empirische Untersuchung von Schülerkarrieren in der Stadt Bremen. Frankfurt am Main: Peter Lang.

Kristen, C. \& Dollmann, J. (2010). Sekundäre Effekte der ethnischen Herkunft: Kinder aus türkischen Familien am ersten Bildungsübergang. In B. Becker \& D. Reimer (Éd.), Vom Kindergarten bis zur Hochschule. Die Generierung von ethnischen und sozialen Disparitäten in der Bildungsbiographie (pp. 117-144). Wiesbaden: VS Verlag.

Kristen, C. \& Granato, N. (2007). The educational attainment of the second generation in Germany: Social origins and ethnic inequality (IAB Discussion Paper No. 4/2007). Nürnberg: Institut für Arbeitsmarkt- und Berufsforschung (IAB).

Loveless, T. (1999). The tracking wars: State reform meets school policy. Washington, DC: Brookings Institution Press.

Mauthe, A. \& Rösner, E. (1998). Schulstruktur und Durchlässigkeit: Quantitative Entwicklungen im allgemeinbildenden weiterführenden Schulwesen und Mobilität zwischen den Bildungsgängen. In H.-G. Rolff, K.-O. Bauer, K. Klemm \& H. Pfeiffer (Éd.), Jahrbuch der Schulentwicklung Band 10: Daten, Beispiele und Perspektiven (pp. 87-125). Weinheim: Juventa. 
Meyer, J. W. \& Ramirez, F. O. (2005). Die globale Institutionalisierung der Bildung. In J. W. Meyer \& G. Krücken (Éd.), Weltkultur: Wie die westlichen Prinzipien die Welt durchdringen (pp. 212-234). Frankfurt am Main: Suhrkamp.

MENFP (2011). Les chiffres clés de l'Éducation nationale: Statistiques et indicateurs 2009-2010. MENFP, Luxembourg.

MENFP. (2012). Que faire après la classe de 9e? Luxembourg: MENFP. Retrieved from https:// portal.education.lu/Portals/18/Que\%20faire\%20apre\%CC\%80s\%20la\%209e.pdf

MENFP. (2013). Réforme du lycée. Réponse du MENFP aux propositions de la délégation nationale des enseignants des lycées (DNL). Luxembourg: MENFP.

MENFP, SCRIPT \& EMACS. (2007). PISA 2006: Nationaler Bericht Luxemburg. Luxemburg: MENFP, SCRIPT \& EMACS. Retrieved from http://www.men.public.lu/catalogue-publications/secondaire/etudes-internationales/pisa-2006/2006-fr.pdf

Oakes, J. (2005). Keeping track: How schools structure inequality. New Haven, CT: Yale University Press.

Pfeffer, F. (2008). Persistent inequality in educational attainment and its institutional context. European sociological review, 24, (5), 543-565.

Schaltz, P. \& Klapproth, F. (2014). The effect of ability-based tracking in secondary school on subsequent school achievement: A longitudinal study. British journal of education, society \& behavioural science, 4, (4), 440-455.

Schindler, S. (2015). Soziale Ungleichheit im Bildungsverlauf - alte Befunde und neue Schlüsse? Kölner Zeitschrift für Soziologie und Sozialpsychologie, 67, (3), 509-537.

Schindler, S. (2017). School tracking, educational mobility and inequality in German secondary education: Developments across cohorts. European Societies, 19, (1), 24-48.

Schreiber, C. (2014). Curricula and the making of the citizen. Trajectories from the $19^{\text {th }}$ and $20^{\text {th }}$ century Luxembourg. Unveröffentlichte Dissertation, Universität Luxemburg.

STATEC Institut national de la statistique et des études économiques. (2014). Luxemburg in Zahlen. Luxemburg: STATEC. Retrieved from http://www.statistiques.public.lu/ catalogue-publications/luxembourg-en-chiffres/2015/luxemburg-zahlen.pdf

Stubbe, T. C. (2009). Bildungsentscheidungen und sekundäre Herkunftseffekte: Soziale Disparitäten bei Hamburger Schülerinnen und Schülern der Sekundarstufe I. Münster: Waxmann.

Van de Werfhorst, H. G. \& Mijs, J. J. B. (2010). Achievement inequality and the institutional structure of educational systems. Annual review of sociology, 36, 407-428.

Keywords: Educational trajectories, transitions, educational inequalities, education system, permeability

\section{Bildungslaufbahnen durch die luxemburgische Sekundarstufe. Wie wirkt sich Durchlässigkeit zwischen Schulformen auf Bildungsungleichheiten aus?}

\section{Zusammenfassung}

In empirischen Studien zeigt sich ein Zusammenhang zwischen dem Stratifizierungsgrad von Bildungssystemen und Bildungsungleichheiten. Zur Reduktion von Ungleichheiten wird - insbesondere dort, wo ein Gesamtschulsystem nicht zu den Alternativen zählt - die Möglichkeit der Erhöhung der Durchlässigkeit zwischen Schulformen diskutiert. Dieser Beitrag untersucht, ob sich das stratifizierte Bildungssystem von Luxemburg als durchlässig erweist und was eine 
solche Durchlässigkeit für bestimmte Risikogruppen bedeutet (Sozialschwache, Jungen, Migrantinnen und Migranten). Auf Basis eines administrativen Paneldatensatzes ( $\mathrm{n}=5301)$ werden mithilfe einer Clusteranalyse Bildungslaufbahnen typisiert und Regressionsmodelle geschätzt, um die Mechanismen hinter Laufbahnentscheidungen zu analysieren (Boudon, 1974). Die Befunde zeigen, dass Re-Orientierungen sich je nach sozialer Gruppe unterscheiden und Durchlässigkeit - als aufgeweichte Bildungsgrenzen - Bildungsungleichheiten in Luxemburg tendenziell verfestigt statt sie zu reduzieren.

Schlagworte: Bildungslaufbahnen, Transitionen, Bildungsungleichheiten, Bildungssystem, Durchlässigkeit

\section{Trajectoires scolaires au sein de l'école secondaire du Luxembourg: les effets de la perméabilité sur les inégalités de formation}

Ré sumé

Des études récentes montrent la corrélation entre stratification des systèmes scolaires et inégalités scolaires. Pour pallier ces inégalités, une plus grande perméabilité - notamment l'aménagement de passerelles entre les filières scolaires - est généralement préconisée. Cette contribution se penche sur cette question dans le contexte du système éducatif luxembourgeois et examine les conséquences de la perméabilité pour trois groupes à risque: les élèves économiquement défavorisés, les migrants et les garçons. Dans un premier temps, les parcours scolaires ont été classés au moyen d'une analyse typologique (cluster analysis) d'un corpus de données d'un panel administratif $(\mathrm{n}=5301)$. Dans un second temps, les mécanismes en jeu dans les décisions concernant l'orientation scolaire ont été analysés par une régression logistique (Boudon, 1974), afin d'identifier les facteurs ayant présidé à ces décisions. Nous concluons d'une part que l'utilisation de la réorientation scolaire dans le système scolaire luxembourgeois est influencée par des facteurs sociaux, d'autre part que le degré de perméabilité actuel, du fait qu'il brouille les frontières éducatives, contribue plutôt à reproduire les inégalités scolaires qu’à les réduire.

Mots-clés: Trajectoires scolaires, transition, inégalités scolaires, système éducatif, perméabilité 


\section{Percorsi formativi nella scuola secondaria in Lussemburgo. Come il grado di permeabilità influisce sulle disuguaglianze educative tra i vari tipi di scuola.}

$\mathrm{Ri}$ assunto

Studi recenti mostrano i legami esistenti tra stratificazione dei sistemi scolastici e disuguaglianze educative. Al fine di ridurre tali disparità - soprattutto nel caso in cui non sussista l'alternativa di un livello secondario unificato - viene auspicata una maggiore permeabilità tra i vari tipi di scuola. Questo contributo esamina tale questione sulla base del sistema educativo del Lussemburgo e si interroga sulle conseguenze della permeabilità per tre gruppi a rischio: allievi socialmente svantaggiati, maschi e immigrati. Dapprima vengono differenziati i percorsi scolastici tramite clustering dei dati di un panel amministrativo $(n=5301)$. In seguito tramite modelli di regressione logistica vengono identificati i fattori determinanti per le scelte di formazione (Boudon, 1974). I risultati mostrano da una parte che l'utilizzo del riorientamento scolastico in Lussemburgo sottostà a meccanismi di selezione sociale. D'altra parte il grado di permeabilità attuale - sotto forma di frontiere educative sfuocate - contribuisce a riprodurre le disuguaglianze scolastiche, invece di ridurle.

Parole chiave: Percorsi formativi, transizione, disuguaglianze educative, sistema educativo, permeabilità 